\title{
RACIAL THREAT AND PARTISAN IDENTIFICATION
}

\section{MICHEAL W. GILES and KAENAN HERTZ Emory University}

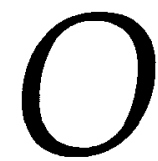

ver the past three decades, as the Democratic party in the South has come to depend more heavily on black voters for its success, it has experienced a decline among white adherents. Power theory views relationships between groups as a function of their competitive positions in political, economic, and social arenas. In contexts where the threat posed by a minority group is high, the dominant group's response is predicted to be more hostile than in contexts where that threat is low. A pooled time series analysis of voter registration data for Louisiana parishes for 1975-90 provides support for the operation of the threat mechanism. Higher black concentrations are associated with declines in the percentage of white registered voters who are Democrats and an increase in the percentage who are Republicans. Consistent with the expectations of power theory, this relationship is conditioned by the social status of the parish.

$\mathbf{T}$ he past three decades have witnessed two dramatic trends in southern politics. First, beginning with the Voting Rights Act of 1965, there has been an extraordinary increase in political participation among southern blacks. This mobilization has been directed almost entirely to the Democratic party. Second, commencing at about the same time, a steep decline has occurred in the identification of southern whites with the Democratic party. This decline has been accompanied by a limited growth in Republican identification in the region and a large increase in the number of southern whites who identify as Independents. The end product of these trends has been twofold. On the one hand, the once solidly Democratic South no longer can be said to have a majority party (Black and Black 1987, 232). On the other hand, the Democratic party that once championed racial segregation in the region has come increasingly to depend upon black voters for its success and, thus, to reflect a more multiracial set of policy preferences.

Several authors have suggested that there is a relationship between the rise of black influence within the Democratic party and the decline of that party's fortunes among white voters (Black and Black 1987; Carmines and Stimson 1989; Huckfeldt and Kohfeld 1989; Lamis 1988, 299; Parent 1988, 209; Sundquist 1983, 400-403; for an opposing view, see Beck 1977; Stanley 1987; Stanley and Castle 1988). ${ }^{1}$ One source of theoretical support for such a linkage can be found in the power theory of intergroup relations (Giles and Evans 1986). ${ }^{2}$ This approach views relationships between groups as a function of their competitive positions in political, economic, and social arenas. This competition is conceptualized as contextually conditioned. In contexts where the threat posed by a minority group is high, the dominant group's response is predicted to be more hostile than in contexts where that threat is low. The operation of such a dynamic in American race relations has been supported by research linking the level of black concentration in an area to the level of various forms of white hostility; lynching (Corzine, Creech, and Corzine 1983), resistance to school desegregation (Giles, Cataldo, and Gatlin 1975; Pettigrew 1957), attitudinal support for racial integration (Fossett and Kiecolt 1989), and voting for racist candidates (Black 1973; Wright 1977).

Of the advocates for a linkage between black influence and white decline in the Democratic party, the argument of Huckfeldt and Kohfeld (1989) most closely parallels that of the power approach. They argue that the defection of white Democrats is a direct response to the threat that black voters pose to white hegemony within the party, and they conceptualize this black threat as contextually specific (pp. 46-47, 106). And, "the severity of racial incompatibility within the [Democratic] coalition, and the attendant unraveling of the coalition, are dependent upon the relative size and intersection of racial groups in particular settings" (p. 41). Moreover, they view the process of threat and defection as self-accelerating. As whites defect from the Democratic party, the party becomes more heavily dependent upon black support which in turn leads more whites to defect: "Racially polarized politics is not a simple function of individually based racist impulses. It is also the product of the progressive transformation of party coalitions that is consequent of these antagonisms" (p. 106). Huckfeldt and Kohfeld find support for their thesis in the 1984 presidential election where the percentage of whites voting for the Democratic candidate decreased as the percentage of blacks in the state's coalition increased $(1989,52)$.

The power approach leads us to expect that members of the dominant group situated in higher-threat contexts will respond more negatively toward the minority than will those situated in lower-threat contexts. However, since the extent to which members of the dominant group compete with the minority varies, the effect of minority threat may not be constant across all members of the dominant group even under similar contextual circumstances (Giles and Evans 1986). Those dominant group members most directly in competition with the minority are expected to be most sensitive to the level of threat 
that it presents to dominant group power in a particular context. Since blacks are more likely to be employed in lower-status unskilled and semiskilled occupations, whites in similar occupations are more directly threatened by black advances. Moreover, lower-status whites also are more likely to compete with blacks for housing and for control of public facilities, such as schools and parks (Giles and Evans 1985; Labovitz and Hagedorn 1975). Thus, the power approach suggests that white reactions to the growth in influence of blacks within the Democratic coalition is conditioned by social status. Lower-status whites are expected to be more sensitive than higher-status whites to this threat and thus more likely to leave the party. Consistent with this expectation, Huckfeldt and Kohfeld found that the negative relationship between the percentage of whites voting for the Democratic candidate in 1984 and the percentage of a state's Democratic coalition that was black was stronger among low-income whites than among highincome whites $(1989,49)$.

The relationship between social class and Democratic support, however, may not be as straightforward as suggested by power theory. Black threat constitutes a force pushing lower-class whites toward exiting the Democratic party but there has been little to pull this group toward the Republicans (Huckfeldt and Kohfeld 1989). With the exception of their appeals to fundamentalists, the Republicans have not actively recruited support from among white lower classes. They have instead built their electoral coalition from the apex of the the social structure downward (Black and Black 1987, 249, 275; Sundquist 1983, 364-67). This may be particularly true for Louisiana in the 1980s, where Parent sees the Republican party as a coalition of white-collar, affluent suburban whites $(1988,216)$. Thus even if lower-status whites are more sensitive to black threat, this may be counteracted by a perception of the Republican party as not responsive to their interests. The final result could be that lower-status whites remain in the Democratic party despite their concerns or that they exit to become Independents rather than Republicans.

Racial sensitivity within a dominant group also may not be constant across time. Events occurring either within or outside of the local context may cause the salience of race-and hence the response of whites to racial threat-to vary. One such event in recent political history was the presidential candidacy of Jesse Jackson. Huckfeldt and Kohfeld argue that the candidacy of Jesse Jackson "could not help but increase the salience of race as a dividing line between Democrats and Republicans" $(1989,108)$. This theme was reiterated by Tyrone Brooks, a black Georgia state legislator, "I believe Jackson's candidacy may in fact contribute to the further alienation of conservative whites and Democrats who will go and vote Republican in the General Election" (quoted in Lamis 1988, 299). Thus, we would expect a surge of white defections from the Democratic party during the 1984 and 1988 presidential campaigns.

The present study reexamines the relationship be- tween black political threat and the decline in white support for the Democratic party. Adopting the power approach, we hypothesize that as blacks constitute a larger component of a given political context, defection of white voters from the Democratic party will increase. Moreover, we hypothesize that this relationship will be conditioned by white social class and will vary temporally with the salience of race in the political arena.

\section{MODELING DEFECTION}

Official voter registration data for all 64 Louisiana parishes (counties) in the time period from 1975 through 1990 are employed to examine these hypotheses. Given its contextual nature, testing the power hypothesis necessitates information on the partisan identification of whites within areal units. Voter registration data in Louisiana are particularly well suited for this purpose. Since 1975, the state of Louisiana has provided data on the number of registered voters in each parish broken down by race and party. ${ }^{3}$ Louisiana is one of only two states to provide such information and the only state for which such data are available on an annual basis. ${ }^{4}$

Louisiana is also an interesting case because of its adoption of an "open" primary system in 1975 (Lamis 1988, 112-13; Parent 1988, 212-13). Under this system candidates from all parties run in the same primary. The candidate who receives a majority of the votes cast is elected to office. If no candidate receives a majority, then a general election is held between the top two candidates. Unlike a "closed" primary, the Louisiana system does not penalize registration as an Independent nor registration as a member of a perpetual minority party. For example, a voter so disposed can register as a Republican and still participate in the choice between two Democratic candidates for the governorship.

The adoption of the open primary in 1975 makes that year the reasonable starting point for examining the effect of black threat on growth in Republican registration. Black registration increased dramatically in Louisiana after the 1965 Voting Rights Act, growing from approximately 240,000 in 1966 to approximately 400,000 in 1975 . This growth constituted an increased threat to white hegemony within the Democratic party but, given the monopoly that the Democratic party maintained over office holding, the closed primary meant that registering as an Independent or a Republican essentially removed the voter from effective participation in electoral politics. As a result, Republican registration increased prior to 1975 , but the growth in absolute numbers was fairly small from approximately 20,000 in 1966 to slightly more than 50,000 in 1975 . The principle response of whites to increasing black threat during this period was not to desert the Democratic party but to countermobilize. Thus, while the percentage growth in the registration of black voters exceeded that of whites between 1966 and 1975 (42\% and 25\%, respec- 
tively), the growth of white registrants in absolute terms was twice that of black registrants $(361,000$ and $177,000)$. It is noteworthy that the tendency of whites to mobilize in response to black threat continued in the period under study. Between 1975 and 1990, parishes with higher black populations were characterized by a higher percentage of registration among the white voting-age population. The higher the black concentration in the population, the more likely eligible whites were to register to vote. ${ }^{5}$

Most studies focusing on changes in partisan identification have relied either on survey responses or electoral results. Both of these are susceptible to the short-term factors that surround elections and so may indicate more volatility among the electorate than actually exists (Brodsky 1988). Voter registration, which requires an expenditure of time and effort by the individual, would appear to be less susceptible to such short-term factors. On the other hand, the requirement of effort, as well as strategic considerations, suggests that some voters will maintain official registration with one party while voting for, and attitudinally identifying with, another. Absent major strategic considerations, like the closed primary, the pressure for cognitive consistency should motivate such individuals eventually to alter their registration to match their voting behavior and attitudes. This movement toward consistency, however, need not be rapid or complete. Thus, official voter registration statistics probably present a conservative estimate of voter change and thus a conservative test of the hypotheses. This conservative bias is to some extent offset by the richness of the voter registration data for Louisiana, which provide more detailed longitudinal information than is available through the use of either surveys or election results.

White defection from the Democratic party can take two forms: movement to Independent identification and movement to Republican identification. These are measured straightforwardly as the percentage of white voters registered as Independent and Republican in a parish for a given year. Since both the relationship between these two forms of defection and the relation of each to black threat is uncertain, they will be treated as separate dependent variables in the analysis.

One possible measure of racial threat to white political hegemony is the percentage of the total Democratic registration that is black. This provides a precise measure of the dependence of the Democratic party on black voters and thus of the racial threat to white control of the party. There are two potential problems with employing this operationalization in the present study. The first is that an arithmetic relationship exists between racial threat operationalized in this manner and the dependent variable of interest. ${ }^{6}$ Whites may be leaving the Democratic party for a variety of nonracial reasons (e.g., more conservative positions regarding defense policy), rather than because of higher black concentrations in the Democratic party, and these departures, by reducing the Democratic base (i.e., the denominator) necessarily results in a higher percentage of blacks within the Democratic party. Simply put, the causal flow may be from growth in Independent and Republican identification to increases in the percentage of blacks within the Democratic party, rather than vice versa, as hypothesized here.

The second problem with using this operationalization is that it requires a presumption that whites are aware of and sensitive to the racial balance among registered voters. While the relevant context for assessing a contextual hypothesis is often problematic, it would seem more likely that whites would be aware of and sensitive to the racial balance in the population at large than among voter registrants.

Given these concerns, racial threat is operationalized in the present study as the percentage of the voting-age population in each parish that is black. Conceptually, this is an indicator of the potential threat that blacks pose to white political hegemony in each parish generally and within the Democratic party specifically. Empirically, this measure of potential threat is strongly linked $(r=.82)$ to the actual percentage of registered Democrats in each parish who are black. The lack of a perfect relationship between these two measures probably reflects the operation of the arithmetic process noted, as well as social and political processes relevant to mobilization (e.g., parish differences in socioeconomics, the presence of voter registration organizations). ${ }^{\text {? }}$

Since population data are only available through the census, interpolation was employed to estimate the size of the total and black voting eligible populations in the years between 1970,1980 and 1990. In the analysis that follows, racial threat is modeled as having a one-year lagged effect. This allows for a reasonable delay between recognition of the level of racial threat and the response of registering as an Independent or Republican.

As noted, considerable research has found racial concentration to be perceived as a threat by southern whites. Much of this research, however, focused on earlier time periods. It might be argued that after prolonged experience with blacks as voters, whites no longer perceive higher concentrations of potential black voters as a threat. The evidence for Louisiana indicates that this is not the case. White electoral support for David Duke, an avowed racist, in his candidacy for the U.S. Senate in 1990 and the governorship of Louisiana in 1991 was positively linked to the percentage of registered voters who were black (Giles and Buckner 1993). The greater the concentration of blacks among the registered voters in a parish, the greater the percentage of registered whites who voted for Duke. Thus, the evidence supports the operationalization of racial threat in terms of the level of black concentration.

The influence of the Jackson candidacy is captured by two dummy variables. The first is scored 1 for 1983 and 1984 and 0 for the remaining years, and the second is scored 1 for 1987 and 1988 and 0 for the remaining years.

The social status of whites within the parishes is 


\section{FIGURE 1}

White Voter Registration by Party in Louisiana, 1975-90

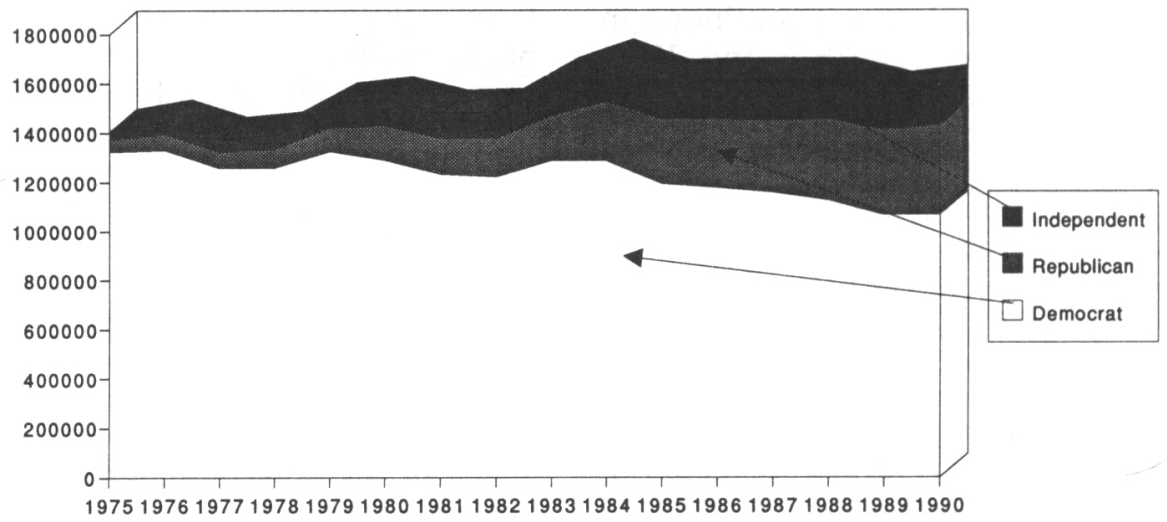

measured using white median household income as reported in the 1980 census. The decision was made to use "household" rather than "family" income since the former more closely taps the social structure present in the living quarters of individuals. Since the principal focus is on lower-class whites, information was also collected on the percentage of whites below the poverty level in the parishes. As might be expected, this indicator is strongly related to median income $(r=-.85)$. Accordingly, only median income is employed in the following analysis.

Quite apart from the racial threat in a particular parish, growth in Independent and Republican identification may reflect statewide and national trends. This factor is taken into account by the inclusion of a simple "counter" variable set to 0 in 1975 and incremented by 1 in each year to $1990 .{ }^{8}$ Likewise, while voter registration is expected to be more stable than responses to party identification items on surveys, it cannot be assumed that registration is completely immune to the short-term factors associated with elections and, in particular, may reflect differentials in voter registration efforts by parties. To allow for such effects, a dummy variable is constructed that is 1 in presidential election years and 0 otherwise.

\section{ANALYSIS}

Figure 1 presents the changes between 1975 and 1990 in Democratic, Republican, and Independent registration among white voters in Louisiana. In 1975, less than $4 \%$ of Louisiana voters were registered as Republicans. By 1990, that number had grown to approximately $23 \%$. Likewise, Independent identification increased from approximately $2 \%$ to approximately $9 \%$ among white registrants. Coincident to the increase in Republican and Independent registrants, the number of Democratic registrants declined not only as a percentage of white registrants but in terms of absolute numbers, as well. In 1975, roughly 1.3 million whites registered as Democrats in Louisiana. By 1990, that number had declined to less that
1.1 million. However, overall white registration increased during this 15-year period, from 1.4 million to slightly less than 1.6 million. These data suggest not only that registrants defected from the Democratic party but also that new white registration disproportionately favored Independents and Republicans. Thus, voter registration among whites in Louisiana tracks reasonably well the declining fortunes of the Democratic party and the rise of Republicans and Independents chronicled by various observers of southern politics.

Is this pattern linked to the level of racial threat in the context? This question is examined at the parish level in Table 1 . Since these are pooled time series data (64 parishes over 16 years), a cross-sectionally correlated and timewise autoregressive approach was used to estimate the effect parameters of our model. ${ }^{9}$ The ordinary least squares approach to pooled time series employing dummy variables assumes that the cross-sectional units are independent (i.e., homoscedastic) (Stimson 1985). This assumption is unlikely to be true when the pooled units are geographic areas, such as parishes (Kmenta 1986). The approach adopted here not only assumes heteroscedasticity but also assumes mutual correlation of error terms and autoregression.

Table 1, equation 1, presents the effects of the independent variables on the percentage of whites registering as Independent. Consistent with expectations, the year counter is statistically significant, indicating that the level of Independent registration among whites has generally increased over the time period under examination. The model predicts an increase of roughly $6 \%$ over the 16 years of the study $(16 * .0038=.0608)$. Likewise, higher median incomes in parishes are associated with higher Independent identification. An increase of $\$ 3,500$ in median income (the standard deviation for income) yields an estimated increase of roughly $1 \%$ in Independent identification. Contrary to expectations, increases in white registration as Independent do not seem to have been influenced by the presence of a presidential election. However, the presence of Jack- 


\section{TABLE 1}

Effect of the Independent Variables on the Percentage of Whites Registered as Independent, Republican, and Democrat (\%)

\begin{tabular}{|c|c|c|c|c|c|c|}
\hline \multirow[b]{2}{*}{ INDEP. VARIABLES } & \multicolumn{2}{|c|}{ INDEPENDENT } & \multicolumn{2}{|c|}{ REPUBLICAN } & \multicolumn{2}{|c|}{ DEMOCRATIC } \\
\hline & $\begin{array}{c}\text { EQUATION } \\
1 \\
\end{array}$ & $\begin{array}{c}\text { EQUATION } \\
2 \\
\end{array}$ & $\begin{array}{c}\text { EQUATION } \\
\mathbf{3} \\
\end{array}$ & $\begin{array}{c}\text { EQUATION } \\
4 \\
\end{array}$ & $\begin{array}{c}\text { EQUATION } \\
5 \\
\end{array}$ & $\begin{array}{c}\text { EQUATION } \\
6\end{array}$ \\
\hline $\begin{array}{l}\text { \% black (lagged) } \\
\text { Year count } \\
\text { Election year } \\
\text { Jackson } 83 / 84 \\
\text { Jackson } 87 / 88 \\
\text { Median income (in }\end{array}$ & $\begin{array}{l}.0126 \\
.0038^{\star \star \star} \\
.0002 \\
.0049^{\star \star \star} \\
.0033^{\star \star \star}\end{array}$ & $\begin{array}{l}.1161^{\star} \\
.0038^{\star \star \star} \\
.0002^{\star 0050^{\star \star \star}} \\
.0034^{\star \star \star}\end{array}$ & $\begin{array}{r}.0907^{\star \star \star} \\
.0107^{\star \star \star} \\
.0069^{\star \star \star} \\
-.0033^{\star \star \star} \\
-.0060^{\star \star \star}\end{array}$ & $\begin{array}{r}.4066^{\star \star \star} \\
.0109^{\star \star \star} \\
.0069^{\star \star \star} \\
-.0033^{\star \star \star} \\
-.0060^{\star \star \star}\end{array}$ & $\begin{array}{l}-.0932^{\star \star \star} \\
-.0148^{\star \star \star} \\
-.0072^{\star k \star} \\
-.0022^{\star *} \\
.0027^{\star \star \star}\end{array}$ & $\begin{array}{l}-.3433^{\star \star *} \\
-.0149^{\star \star \star} \\
-.0072^{\star \star \star} \\
-.0021^{\star \star} \\
.0027^{\star \star \star}\end{array}$ \\
\hline $\begin{array}{l}\text { thousands) } \\
\text { Med. Income } \times \%\end{array}$ & $.0032^{\star \star \star}$ & $.0047^{* * *}$ & $.0032^{\star \star \star}$ & $.0083^{\star \star \star}$ & $-.0067^{\star \star \star}$ & $-.0112^{\star \star \star}$ \\
\hline black (lagged) & - & $-.0065^{\star}$ & - & $-.0214^{\star \star *}$ & - & $.0152^{\star}$ \\
\hline $\begin{array}{l}\text { Constant } \\
\text { Buse } \mathrm{R}^{2}\end{array}$ & $\begin{array}{c}-.0330^{\star \star} \\
.597^{b}\end{array}$ & $\begin{array}{l}-.0573^{\star \star} \\
.593\end{array}$ & $\begin{array}{l}-.0676^{\star \star \star} \\
.854\end{array}$ & $\begin{array}{c}-.1445^{\star \star \star} \\
.861\end{array}$ & $\begin{array}{c}1.1043 \\
.853\end{array}$ & $\begin{array}{l}1.1795^{\star \star \star} \\
.864\end{array}$ \\
\hline \multicolumn{7}{|c|}{$\begin{array}{l}\text { Note: Unstandardized regression coefficients are estimated using Shazam, Version } 6.2 \text {. See } \mathrm{n} .10 \text { for details. } \\
\text { aq black = (the black voting-age population)/(the total voting-age population) lagged one year } \\
\text { "Buse } \mathrm{R}^{2} \text { is analogous to the normal } \mathrm{R}^{2} \text { applied to the transformed data. } \\
.05 \\
+* .01 \\
\mathrm{~N} .001 \\
\mathrm{~N}=960 \text { (64 parishes } / 15 \text { years) }\end{array}$} \\
\hline
\end{tabular}

son in a presidential campaign does appear to increase racial sensitivities and result in slightly increased white registration as Independent. Most importantly, however, these data provide no support for the white backlash hypotheses. There appears to be no simple relationship between the black concentration in the parish population and the percentage of whites that register as Independent.

Table 1 , equation 3 , presents the effects of the independent variables on the percentage of whites registered as Republicans. Consistent with expectations, the level of black concentration within the voting-age population is positively linked to the percentage of white voters in a parish registered as Republicans. An increase of $10 \%$ in the black concentration is predicted to result in an increase of approximately $1 \%$ in white Republican registration (.10* $.0907=.009$ ). While this effect is not substantively large, it is consistent with the idea that Republican growth reflects, in part, a response to racial threat within the local context.

Also consistent with expectations, the year counter indicates an increase in Republican registration across the time period: An approximate $1 \%$ increment in Republican registration is estimated to occur with the passage of each year. Unlike the case for Independent registration, white registration as Republican increases on average about one-half of $1 \%$ in presidential election years. Apparently, the stimulus toward registration in presidential years carries with it a partisan valence. As expected, parishes with higher median incomes tend to have higher percentages of white voters registered as Republicans. It is interestIng to note that the effect of this variable on the level of Republican identification is essentially the same as its effect on Independent identification.

The major departure from expectations is the effect of the Jackson campaigns. While Jackson's candidacy is significantly associated with the percentage of whites registering as Republicans, the direction of the effect is opposite to that predicted. The percentage of whites registering as Republicans was expected to be higher during Jackson's campaigns in response to heightened racial sensitivity. However, with the effects of the other variables in the model taken into account, the period of the Jackson campaigns is associated with somewhat lower predicted white Republican registration. It should be emphasized that this does not mean that the level of Republican white registration would be lower in absolute terms but rather that the upward trajectory flattened out somewhat during these periods. Alternatively, one could say that the spike in white Republican registration associated with election years is somewhat attenuated during the elections in which Jackson was a candidate.

Table 1, equation 5 presents the effects of the independent variables on the percentage of whites registered as Democrats. Within rounding, these results are a summation of equations 1 and 3 . Equation 5 basically shows the negative effect that nearly all of the independent variables had on the percentage of whites registering as Democrats, while equations 1 and 3 show where those defections went. For Democrats, every passing year yields a further decline in the share of registered whites. This decline is higher in election years and increases with the median income of the white population in the parish. Jack- 
son's first presidential bid accentuated this election year decline, but his second campaign had a positive effect on the Democratic share of white registrants. Again, this does not mean that the actual percentage of whites registering as Democrats increased in this time period. The negative effect of the election year variable is more than twice that of the positive effect of the second Jackson candidacy. Thus the decline in Democratic registration among whites was only somewhat lessened during Jackson's second campaign. While these data are inconclusive as to whether the Jackson candidacy "pushed" whites away from the Democratic party, the negative signs of the Jackson variables in equation 3 make it clear that, at least in the short term, there was no "pull" toward the Republican party as a result of his candidacy.

Based on the power model, we hypothesized that the effects of racial threat would be conditioned by social status, with threat having greater effect among lower-status whites than among higher-status whites. This hypothesis is examined by fitting a multiplicative interaction term between white median income and \% black in the population. The results of this analysis are reported in equation 2 for Independents, equation 4 for Republicans and equation 6 for Democrats. For both Independents and Republicans, the interaction term is negative and statistically significant. Substantively, this result is consistent with the expectations of the power model. The positive effect of racial threat on the growth of Independent and Republican registration is diminished as the median white income of the parish increases. The positive interaction effect in equation 6 means that the decline in white Democratic registration arising with increases in racial threat is attenuated within higher white income contexts. ${ }^{10}$

The model fitted to this point has assumed that the effect of racial threat remained constant during the study period. This assumption is examined in Table 2 , where the effects of the percentage of blacks and median income are estimated in biannual cross-sections from 1976 through $1990 .{ }^{11}$ Since the remaining variables considered in the original model vary only temporally, their effects cannot be estimated in this analysis. The effects of the percentage of blacks are estimated separately for parishes above and below the mean for white income. This allows the interaction effect between \% black and white income identified in Table 1 to be presented in a more easily interpretable form.

The results in Table 2 for white registration as Independent do not suggest any patterned shift during the study period in the salience of racial threat. For all the cross-sections, the effect of the percentage of blacks on the percentage of whites registering as Independent is not statistically significant. Using pooled time series in Table 1, the effect of the percentage of blacks on the percentage of whites registering as Independent appeared to be conditioned by white income. This is reflected in the relatively stronger effect that percentage of blacks has on independent registration among lower-income parishes than among higher-income parishes in Table 2. These differences are simply not of sufficient magnitude to obtain statistical significance when decomposed into cross sections.

In contrast, the results in Table 2 for the effect of the percentage of blacks on the percentage of whites registered as Republicans illustrate the conditioning influence of white income and also reveal a patterned shift in the salience of racial threat. First, consistent with the findings in Table 1 and with the expectations of the power hypothesis for every cross section, the effect of the percentage of blacks is higher in lowwhite-income parishes than in high-white-income parishes. Indeed, in not one cross section does the effect of racial concentration in the voting-eligible population achieve statistical significance in the highincome parishes. Second, while the effects of the percentage of blacks within lower-income parishes are only statistically significant beginning with the 1982 cross section, from 1976 through 1990, the magnitude of the effects of the percentage of blacks on the percentage of Republicans increases. Indeed, between 1980 and 1990, the effect of the percentage of blacks on the percentage of Republicans almost triples. In 1980, a 10-point increase in the percentage of the voting-eligible population who were black is predicted to increase the percentage of whites registered as Republicans by approximately .85 percentage points. In 1990, that same increase is linked to a growth of 2.26 points in the percentage of white Republicans. As required, the results for Democratic registration are the mirror image of those for Republican registration. Thus, during the study period, racial threat to white political control increasingly became an important consideration in the growth of Republican registration and the decline of Democratic registration among whites in Louisiana.

\section{DISCUSSION}

The issue of a linkage between the rise of black influence within the Democratic party and the decline of Democratic identification among whites has been debated in both the popular media and the scholarly press. The presence of such a linkage is consistent with power theory, which views relations among groups as a function of their competitive positions in political, economic, and social arenas. Generally, this approach predicts that the willingness of a dominant group to remain in a particular context declines as its hegemony is threatened by increases in the power of the nondominant group. Thus, as blacks constitute a larger element of the Democratic coalition in a particular context, the power approach predicts that whites will increasingly exit the party. Moreover, this approach suggests that the response among whites will be conditioned by their vulnerability to competition from blacks. Thus, lower-status whites are predicted to be more sensitive than are higher-status whites to the threat posed by higher black concentrations.

The results of the present study provide support 


\section{TABLE 2}

Cross-sectional Examination of the Interactive Effects of the Percentage of Blacks and Median Income on Partisan Registration

\begin{tabular}{|c|c|c|c|c|}
\hline \multirow[b]{2}{*}{$\begin{array}{c}\text { DEPENDENT } \\
\text { VARIABLES } \\
\text { YEAR AND PARTY } \\
\end{array}$} & \multicolumn{3}{|c|}{ COEFFICIENTS FOR INDEPENDENT VARIABLES } & \multirow[b]{2}{*}{ R-SQUARE } \\
\hline & $\begin{array}{c}\text { PERCENT BLACK } \\
\text { IN LOWER } \\
\text { INCOME PARISHES }\end{array}$ & $\begin{array}{c}\text { PERCENT BLACK } \\
\text { IN HIGHER } \\
\text { INCOME PARISHES }\end{array}$ & MEDIAN INCOME & \\
\hline \multicolumn{5}{|l|}{1976} \\
\hline Republican & .0086 & -.0258 & $.0034^{\star *}$ & .13 \\
\hline Independent & .0101 & -.0178 & $.0023^{\star \star}$ & .13 \\
\hline \multicolumn{4}{|l|}{1978} & .14 \\
\hline Republican & .0115 & -.0335 & $.0040^{* \star}$ & .14 \\
\hline Independent & .0134 & -.0125 & $.0028^{\star \star}$ & .14 \\
\hline Democrat & -.0249 & .0460 & $-.0068^{\star \star}$ & .15 \\
\hline \multicolumn{5}{|l|}{1980} \\
\hline Republican & $.0850 \#$ & -.0085 & $.0057^{* *}$ & .12 \\
\hline Independent & .0437 & .0079 & $.0047^{\star * *}$ & .23 \\
\hline Democrat & $-.1287 \#$ & .0007 & $-.0103^{\star \star}$ & .17 \\
\hline \multicolumn{5}{|l|}{1982} \\
\hline Republican & $.1109^{*}$ & .0064 & $.0063^{\star \star}$ & .14 \\
\hline Independent & .0328 & .0108 & $.0049 * \star \star$ & .26 \\
\hline Democrat & -.1436 & -.0172 & $-.0111^{\star \star}$ & .18 \\
\hline \multicolumn{5}{|l|}{1984} \\
\hline Republican & $.1546^{\star *}$ & .0065 & $.0091^{\star \star}$ & .18 \\
\hline Independent & .0298 & .0088 & $.0058^{\star \star \star}$ & .29 \\
\hline Democrat & $-.1844^{\star}$ & -.0153 & $-.0149^{\star \star \star}$ & .22 \\
\hline \multicolumn{5}{|l|}{1986} \\
\hline Republican & $.1810^{\star \star}$ & .0018 & $.0106^{\star \star}$ & .19 \\
\hline Independent & .0280 & .0021 & $.0056^{\star \star \star}$ & .19 \\
\hline Democrat & $-.2090^{*}$ & -.0039 & $-.0162^{\star \star \star}$ & .22 \\
\hline \multicolumn{5}{|l|}{1988} \\
\hline Republican & $.2086^{* *}$ & .0111 & $.0115^{\star \star}$ & .19 \\
\hline Independent & .0263 & .0016 & $.0049^{\star \star \star}$ & .24 \\
\hline Democrat & $-.2349^{\star}$ & -.0127 & $-.0165^{\star \star \star}$ & .21 \\
\hline \multicolumn{5}{|l|}{1990} \\
\hline Republican & $.2264^{\star \star}$ & .0144 & $.0119^{\star *}$ & .19 \\
\hline Independent & .0294 & .0048 & $.0046^{* \star}$ & .23 \\
\hline Democrat & $-.2558^{\star \star}$ & -.0192 & $-.0165^{\star \star *}$ & .20 \\
\hline \multicolumn{5}{|c|}{ Note: The ordinary least squares regression coefficients are derived from fitting the following model to the dependent variables: } \\
\hline \multicolumn{5}{|c|}{$\%$ REP or $\%$ IND or $\%$ DEM $=a+b_{1}$ (median income $)+b_{2}(L \times \%$ black $)+b_{3}(H \times \%$ black $)$} \\
\hline \multicolumn{5}{|c|}{ 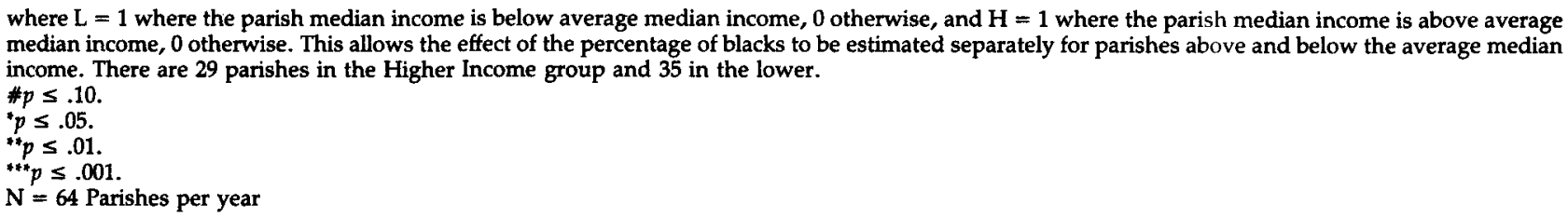 } \\
\hline
\end{tabular}

for the operation of a linkage between increases in black threat and growth in Republican registration. Between 1976 and 1990, Republican registration grew dramatically in Louisiana. At the parish level this increase was found to be related to the black concentration within the voting-age population. The larger the percentage that blacks constituted of the votingage population in a parish, the larger the increase in the percentage of whites registering as Republican. Moreover, this linkage increased steadily in magnitude during the study period. In sum, these data suggest that the increasing influence of blacks within the Democratic coalition was a factor in the growth of
Republican registration in Louisiana and that its importance increased through the 1980s.

The impact of racial threat was also found to be conditioned by white social status as predicted by power theory. Indeed, the relationship identified between black threat and growth in Republican registration was confined almost entirely among parishes with lower white median incomes. Among parishes with higher white median incomes, the level of black concentration appears to be unrelated to growth in Republican registration. These results, combined with the positive relationship between median white income and Republican registration, 
suggest that Republican growth is benefiting from a complex relationship between race and class. Republicans are gaining registration among both higher- and lower-status whites. Among higher-status whites, this shift toward Republican registration probably reflects traditional conservative issue appeals. Among lower-status whites, the shift toward Republican registration appears to reflect concerns about black influence within the Democratic party. Consistent with the argument of Huckfeldt and Kohfeld (1989), the end result of the operation of racial threat among lower-status whites is that the class cleavage between the Democratic and Republican parties is diminished.

These concerns of the lower-status whites should not be interpreted simply as racism, although the willingness of a large number of white Louisiana voters to support David Duke in his campaign for governor suggests that the operation of racism cannot be dismissed. Available evidence indicates that, in fact, blacks have become a larger component of the Democratic coalition, Democratic politicians at both the federal (Whitby, 1987; Whitby and Gilliam, 1991) (2) $^{12}$ and state (Herring, 1990) levels have become more sensitive to black political demands. Thus, whites who exit the Democratic party in response to its increasingly black makeup may be seen as exiting an organization that in reality is less sensitive to their interests.

While providing clear support for the operation of racial threat in the decline of white support for the Democratic party, the results of this analysis also indicate that other factors played a role in this decline. Across the time period examined, the growth of Independent registration was found to be unrelated to the level of black concentration within the Democratic party. Thus, the movement of Democratic registrants into the Independent category does not appear to have been linked to the threat of black influence within the Democratic party. Moreover, the significant effects of the trend and the election-year variables indicate that general forces outside of the parish context were at work in stimulating growth in Republican and Independent registration. The magnitude of the effects for these variables indicates that at least on average, their effects were more important than those of racial threat. However, it should be remembered that registration data provide a conser-

\section{TABLE A-1}

Descriptive Statistics for Principal Variables $(\mathbf{N}=\mathbf{6 4})$

\begin{tabular}{|c|c|c|c|c|}
\hline VARIABLE & MEAN & S.D. & $\begin{array}{l}\text { MINI- } \\
\text { MUM }\end{array}$ & $\begin{array}{c}\text { MAXI- } \\
\text { MUM }\end{array}$ \\
\hline \multicolumn{5}{|l|}{1975} \\
\hline$\%$ black & .28 & .13 & .04 & .62 \\
\hline$\%$ white Republicans & .02 & .02 & .00 & .11 \\
\hline$\%$ white Independents & .01 & .01 & .00 & .05 \\
\hline$\%$ white Democrats & .96 & .03 & .86 & 1.00 \\
\hline \multicolumn{5}{|l|}{1980} \\
\hline$\%$ black & .27 & .13 & .03 & .59 \\
\hline$\%$ white Republicans & .06 & .04 & .02 & .19 \\
\hline$\%$ white Independents & .05 & .03 & .01 & .11 \\
\hline$\%$ white Democrats & .88 & .07 & .72 & .98 \\
\hline \multicolumn{5}{|l|}{1985} \\
\hline$\%$ black & .28 & .13 & .04 & .58 \\
\hline$\%$ white Republicans & .12 & .06 & .03 & .28 \\
\hline$\%$ white Independents & .07 & .03 & .02 & .14 \\
\hline$\%$ white Democrats & .81 & .09 & .59 & .95 \\
\hline \multicolumn{5}{|l|}{1990} \\
\hline$\%$ black & .28 & .13 & .04 & .59 \\
\hline$\%$ white Republicans & .18 & .08 & .07 & .36 \\
\hline$\%$ white Independents & .08 & .03 & .02 & .14 \\
\hline$\%$ white Democrats & .74 & .10 & .50 & .90 \\
\hline
\end{tabular}

vative test of the threat hypothesis and may well underestimate the effects of racial concentration.

\section{APPENDIX}

Table A-1 shows descriptive statistics for selected years for the dependent variables and the percentage of the population that is black.

Table A-2 shows the correlations among the principal dependent and independent variables employed in the analysis.

\section{Notes}

We would like to acknowledge the assistance of our col-
leagues Alan Abramowitz, Merle Black, and Courtney Brown,
who commented on earlier versions of this manuscript.
1 . These authors vary in the importance which they
would attach to racial antagonism in producing defection. For

\section{TABLE A-2}

Correlation Matrix for Pooled Data $(\mathrm{N}=960)$

\begin{tabular}{lcccccc}
\hline & WHITE & \% & \% WHITE & \% WHITE & \% WHITE \\
& INC. & BLACK & REP. & IND. & $\begin{array}{c}\text { DEM. } \\
\text { YEARCOUNT }\end{array}$ \\
\hline White income & 1.0000 & - & - & - & - & - \\
\% black & -.02650 & 1.0000 & - & - & - & - \\
$\%$ white Republicans & .17462 & .11889 & 1.0000 & - & - \\
\% white Independents & .36857 & .04975 & .78275 & 1.0000 & - \\
\% white Democrats & -.24895 & -.10163 & -.97772 & -.89596 & 1.0000 & - \\
Yearcounter & .00000 & -.00110 & .67003 & .54735 & -.66281 & 1.0000 \\
\hline
\end{tabular}


example, Black and Black see white defection as a complex process of which racial antagonism is only one component, a view with which we agree $(1987,271)$.

2. The power approach has also been referred to as the "conflict approach" or "competitive ethnicity" (see Blalock 1967; Blumer 1958; Schermerhorn 1956; Wilson 1973).

3. Louisiana provided total registration by race and by party for each parish prior to 1975 , but party registration was not provided by race. Georgia, North Carolina, and South Carolina provide voter registration data by race, but it is not broken down by party.

4. Registration reports are actually available on a quarterly basis, although only the final quarter reports issued in December of each year are employed in this analysis. Florida provides voter registration reports by race and party every two years during primary and general elections.

5. The effects of the percentage of blacks in the population on the percentage of eligible whites who registered was estimated controlling for (1) white median income, (2) whether Jesse Jackson was campaigning, (3) whether it was an election year, and (4) a trend counter for time. The coefficient for the percentage of blacks was .1315, which was statistically significant at .05.

6. The percentage of blacks within the Democratic party is $\mathrm{BD} /(\mathrm{BD}+\mathrm{WD})$, where $\mathrm{BD}$ equals the number of black Democrats and WD equals the number of white Democrats. The dependent variable is the percentage of whites who are Republican, or WR/(WD + WR + WI), where WR equals the number of white Republicans and WI equals the number of white independents. As WD declines, ceteris paribus, the percentage of blacks in the Democratic party must increase.

7. The analysis was replicated using the percentage of registered Democrats in each parish who are black as the measure of racial threat. While the magnitudes of coefficients varied, the overall pattern of results was not substantially different from that reported here using the percentage of blacks in the population.

8. The trend counter as a surrogate for a general pattern over time has been used by the Bureau of Labor Statistics and econometricians alike (see Maddala 1977, 344-46).

9. The estimation techniques used assume that we have a cross-sectionally correlated and timewise autoregressive model. We therefore assume that the cross sections (the parishes) are not independent over time. The solution to this problem has been suggested by Kmenta $(1971,512-14)$. This model assumes that there is heteroscedasticity, mutual correlation, and autoregression. The procedure to attain efficient estimates involves transforming the variance-covariance matrix with respect to parishes, over time. This has a similar effect to removing the mean over-time value of the variables from each parish.

This is done as a multistep procedure that first involves transforming the residuals with respect to time. This removes the problem of autoregressive behavior. These residuals are then used in an ordinary least squares regression to calculate the regression residuals. The regression residuals are then transformed to remove cross-sectional correlation and create consistent estimates for variance and covariance. These estimates are then used in calculating the parameter estimates.

10. The significant interaction between median income and $\%$ black might be serving simply as a proxy for a nonlinear relationship between median income and the dependent variables. However, as seen in the Appendix, white median income and the percentage of blacks are not statistically related in these data, making this unlikely. Moreover, when median income squared (a nonlinear term) was added to equations 2, 4, 6, its coefficient was not statistically significant, while the interaction term between median income and \% black remained statistically significant. Similar results were obtained when \% black squared was added to these equations.

11. In addition to the analysis in Table 2 , a multiplicative interaction term between the year counter and \% black was added to equations 1,3 , and 5 (Table 1 ). This term was statistically significant for Republican and Democratic registration but not for Independent registration. While patterns appearing in a pooled cross section may not appear in an analysis of the component cross sections or may only be approximated (Stimson 1985), the results in Table 2 appear to capture the patterns of the pool cross section reasonably well.

12. Some studies have found no relationship between the racial concentration in the district and liberal voting. Whitby and Gilliam (1991) provide evidence that racial composition did have such an effect in a transitional period but that by the 1980 s the contribution of black voters to the party extended their influence beyond specific contexts, with the result being a generally greater liberalness among southern Democrats not correlated to racial concentration.

\section{References}

Beck, Paul Allen. 1977. "Partisan Dealignment in the Postwar South." American Political Science Review 71:477-96.

Black, Earl. 1973. "The Militant Segregationist Vote in the Post Brown South: A Comparative Study." Social Science Quarterly 54:66-84.

Black, Earl, and Merle Black. 1987. Politics and Society in the South. Cambridge: Harvard University Press.

Blalock, Hubert M. 1967. Toward a Theory of Minority-Group Relations. New York: John Wiley and Sons.

Blumer, Herbert. 1958. "Race Prejudice as a Sense of Group Position?" Pacific Sociological Review 1:3-7.

Brodsky, David M. 1988. "Partisan Change: An Overview of a Continuing Debate." In The South's New Politics, ed. Robert H. Swansbrough and David M. Brodsky. Columbia: University of South Carolina Press.

Carmines, Edward G., and James A. Stimson. 1989. Issue Evolution: Race and the Transformation of American Politics. Princeton: Princeton University Press.

Corzine, Jay, James Creech, and Lin Corzine. 1983. “Black Concentration and Lynchings in the South: Testing Blalock's Power-Threat Hypothesis." Social Forces 61:774-96.

Fossett, Mark A., and K. Jill Kiecolt. 1989. "The Relative Size of Minority Populations and White Racial Attitudes." Social Science Quarterly 70:820-35.

Giles, Micheal W., and Melanie Buckner. 1993. "David Duke and Black Threat: An Old Hypothesis Revisited." The Journal of Politics 55:702-13.

Giles, Micheal W., Everett Cataldo, and Douglas Gatlin. 1975. "White Flight and Percent Black: The Tipping Point Reexamined." Social Science Quarterly 56:85-92.

Giles, Micheal W., and Arthur Evans. 1985. "External Threat, Perceived Threat, and Group Identity." Social Science Quarterly 66:50-66.

Giles, Micheal W., and Arthur Evans. 1986. "The Power Approach to Intergroup Hostility." Journal of Conflict Resolution 30:469-86.

Herring, Mary. 1990. "Legislative Responsiveness to Black Constituents in Three Deep South States." Journal of Politics 52:740-58.

Huckfeldt, R. Robert, and Carol W. Kohfeld. 1989. Race and the Decline of Class in American Politics. Chicago: University of Illinois Press.

Kmenta, Jan. 1971. Elements of Econometrics. New York: Macmillan.

Kmenta, Jan. 1986. Elements of Econometrics. 2d ed. New York: Macmillan.

Labovitz, Sanford, and Robert Hagedorn. 1975. "A Structural-Behavioral Theory of Intergroup Antagonism." Social Forces 53:444-48.

Lamis, Alexander P. 1988. The Two-Party South. New York: Oxford University Press.

Maddala, G. S. 1977. Econometrics. New York: McGraw Hill.

Parent, Wayne. 1988. "The Rise and Stall of Republican Ascendency in Louisiana Politics." In The South's New Politics, ed. Robert H. Swansbrough and David M. Brodsky. Columbia: University of South Carolina Press.

Pettigrew, Thomas F. 1957. "Demographic Correlates of Bor- 
der-State Desegregation." American Sociological Review 22: 683-89.

Schermerhorn, R. A. 1956. "Power as a Primary Concept in the Study of Minorities." Social Forces 35:53-56.

Stanley, Harold W. 1987. Voter Mobilization and the Politics of Race: The South and Universal Suffrage, 1952-1984. New York: Praeger.

Stanley, Harold W., and David S. Castle. 1988. "Partisan Changes in the South: Making Sense of Scholarly Dissonance." In The South's New Politics, ed. Robert H. Swansbrough and David M. Brodsky. Columbia: University of South Carolina Press.

Stimson, James A. 1985. "Regression in Space and Time: A Statistical Essay." American Journal of Political Science 29:91447.

Sundquist, James L. 1983. Dynamics of the Party System: Align- ment and Realignment of Political Parties in the United States. Rev. Washington: Brookings Institution.

Whitby, Kenny. 1987. "Measuring Congressional Responsiveness to the Policy Interests of Black Constituents." Social Science Quarterly 68:367-77.

Whitby, Kenny, and Franklin D. Gilliam. 1991. "A Longitudinal Analysis of Competing Explanations for the Transformation of Southern Congressional Politics." Journal of Politics 53:504-18.

Wilson, William J. 1973. Power, Racism, and Privilege: Race Relations in Theoretical and Sociohistorical Perspectives. New York: Macmillan.

Wright, Gerald C. 1977. "Contextual Models of Electoral Behavior: The Southern Wallace Vote." American Political Science Review 71:497-508.

Micheal W. Giles is Professor of Political Science and Fellow of the Carter Center, and Kaenan Hertz is Doctoral Candidate in Political Science, Emory University, Atlanta, GA 30322. 